\title{
Effect of Thickness in Carbon Nanotube Electrode Layer for Electrochemi-Luminescence Cells Applications
}

\author{
Pakpoom Chansri*, Pattarapon Pooyodying* and Youl Moon Sung ${ }^{\dagger}$
}

\begin{abstract}
The nanoelectrode layer in electrochemi-luminescence (ECL) cells can be improved the performance of light intensity. In this work, the ECL cells were fabricated using carbon nanotubes (CNT) and Ru(II) complex as a luminescent material. We reported to the effect of the thickness of the CNTs layer in ECL cell. The produced ECL cell consists of F-doped $\mathrm{SnO}_{2}$ (FTO) glass/ $\mathrm{Ru}(\mathrm{II}) /$ thickness of CNTs/FTO glass. At 3.5 V, the measured highest current and highest luminance of CNTsbased on ECL cells was $48 \mathrm{~mA}$ and $15.02 \mathrm{~cd} / \mathrm{m}^{2}$ at CNT-5 $\mu \mathrm{m}$. The maximum of ECL efficiencies was $0.00893 \mathrm{~lm} / \mathrm{W}$ for CNT-5 $\mu \mathrm{m}$. When, the applied voltage increases at $4-5 \mathrm{~V}$ is causing to maximum ECL efficiency for CNTs-based on ECL cell. The peak intensity of thickness of CNTs-based on ECL cell was $\sim 620 \mathrm{~nm}$ of CNTs and $\sim 625 \mathrm{~nm}$ of without CNT, which is a similar color and responded dark orange color, were not affected to the added electrode material. The ECL cell with CNTs showed optimum for light emission was the thickness of CNT- $5 \mu \mathrm{m}$ electrode. The use of CNTs-based on ECL cell significantly improves the ECL efficiency and long-term stability.
\end{abstract}

Keywords: Electrochemi-luminescence (ECL) cells, Carbon nanotube, $\mathrm{Ru}(\mathrm{II})$ complex

\section{Introduction}

Currently, the nanostructure electrode layer widely used in the applications such as a chemical sensor (biosensor), dye-sensitized solar cells (DSSCs), and electrochemiluminescence (ECL) cells. It can be stimulated electron transfer between surface electrodes to material layer increased [1-4]. The ECL cell devices are well known in the light-emitting phenomenon which composed of two electrodes with the transparent conducting oxide (TCO) and luminescent material with $\mathrm{Ru}(\mathrm{II})$ complex layer $[2$, 5-7]. The researchers are interested in the ECL cell devices due to it is simple structure devices. Therefore, the efficiency of ECL cell device is based on the electrode layer that structure electrode is nanostructure electrode. The application of nanostructure electrode is used, metal oxide nano-electrode and one-dimensional structure such as nanoparticles, nanowires, nanotubes, and nanorods. The carbon nanotubes (CNTs) are an alternative that can be applied in ECL cells. It is a semiconductor which can be applied to the electrode of ECL cell.

The nanostructure of CNTs is one-dimensional systems, a synthetic material that gets the most attention. CNTs have a special structure that is different from the three allotropes (diamond, graphite, and buckminsterfullerene). CNTs are formed from carbon atoms arranged in a sheet, which has a high fluidity (Similar to the structure of graphite). The

$\dagger$ Corresponding Author: Dept. of Electrical and Electronic Engineering, Kyungsung University, Korea. (ymsung@ks.ac.kr)

* Dept. of Electrical and Electronic Engineering, Kyungsung University, Korea. (\{pakpoom, pattarapon1990\}@ks.ac.kr)

Received: November 25, 2015; Accepted: May 25, 2015 carbon atoms are coherence into a lattice with hexagonal holes, which is a pipe or a tube [8]. CNTs are very small tubes at the nanometer scale, which has a diameter of tubes in the range of 0.4 to $4.0 \mathrm{~nm}$. It can be a synthesized structure with a length of up to $10 \mu \mathrm{m}$. CNTs can be synthesized by two types; a single wall carbon nanotube (SWCNT) and a multi-wall carbon nanotube (MWCNT) which have band gaps $\sim 0.5 \mathrm{eV}$ at diameter $1.5 \mathrm{~nm}$ [9-11]. The electrical properties of CNTs are semiconductor or superconductor which is based on the synthesis of carbon atoms arranged along the wall of the tube. All properties of CNTs may be applied to the electrode layer in the ECL cell. Often, the research reported in the thickness of the electrode layer which have affected to electrical and optical properties of the ECL cell $[12,13]$. Thus, we are focusing on optimum of the thickness of the CNTs electrode layer on an ECL cell device which may be increased the oxidation and reduction reaction of $\mathrm{Ru}(\mathrm{II})$ complex and recombination between $\mathrm{Ru}(\mathrm{I})$ and $\mathrm{Ru}(\mathrm{III})$ thus the overall conversion efficiency can increase.

In this paper, we present an optimum thickness of CNTsbased ECL cell. In order to, the increased area electrode are the interface between CNTs electrode and $\mathrm{Ru}(\mathrm{II})$ complex in the cell. The CNTs have semiconductor can be received density of electrons on the surface CNTs electrode with $\mathrm{Ru}(\mathrm{II})$ complex. The ECL cell with CNTs was fabricated layers nanostructure via F-doped $\mathrm{SnO}_{2}$ (FTO) glass / $\mathrm{Ru}(\mathrm{II})$ / CNTs / FTO glass. The electrical and optical properties of the CNTs electrode layer of the ECL cell are investigated by each thickness of the CNT layer which is suitable for the ECL device. 


\section{Experimental Setup}

The structure used CNTs electrode for ECL cell device, show in Fig. 1. The thickness of the electrodes between FTO glass is approximately $60 \mu \mathrm{m}$, which was injected with $\mathrm{Ru}(\mathrm{bpy})_{3}{ }^{2+}$. The reason of using FTO glass instead of ITO is because of the excellent heat resistance that eliminates further problems. The CNTs layer with 1-7 $\mu \mathrm{m}$ of thicknesses are connected in 3-D structure with $\mathrm{Ru}(\mathrm{bpy})_{3}{ }^{2+}$. The coated CNTs can be enhanced $\mathrm{Ru}(\mathrm{bpy})_{3}{ }^{2+}$ in the cell because of the surface of CNTs was increased. Thus, the large surface area became very conductive, its can the fast transfer of more electric charges in $\mathrm{Ru}(\mathrm{bpy})_{3}{ }^{2+}$ molecules [14, 15].

The CNTs synthesis has been grown by spin-coating technique can be discussed elsewhere [16]. The CNTs paste solution was fabricated CNTs (muti-wall nanotube: MWNT; Hanwha Nanotech) powder and sodium dodecyl benzene sulfonate (SDBS; CHEMMAX) by mixing in the ratio $20 \mathrm{mg}$ : $20 \mathrm{mg}$, and the deionized water of $20 \mathrm{ml}$ for the surfactant, stirred 10 minutes. The dispersion of CNTs was prepared by bath sonicator (Branson, 2510) for $5 \mathrm{~min}$ and bar sonicator (Sonics \& material, VCX500) for 20 minutes [16-18]. The process of CNTs can be shown Fig. 2.

The synthesis of ECL cell device was used Tris(bipy ridine)ruthenium(II) chloride $\left(\mathrm{Ru}(\mathrm{bpy})_{3} \mathrm{Cl}_{2} ; \quad\right.$ SIGMAAldrich) and ammonium hexafluorophosphate $\left(\mathrm{NH}_{4} \mathrm{PF}_{6}\right.$; WAKO) and propylene carbonate (PC; SIGMA-Aldrich). $\mathrm{Ru}$ (bpy) ${ }_{3} \mathrm{Cl}_{2}$ and $\mathrm{NH}_{4} \mathrm{PF}_{6}(0.5 \mathrm{~g}: 0.5 \mathrm{~g})$ were dissolved in the distilled water, and stirring process of the solution for $1 \mathrm{~h}$.

The both solutions results in the formation $\mathrm{Ru}(\mathrm{bpy})_{3}\left(\mathrm{FP}_{6}\right)_{2}$.

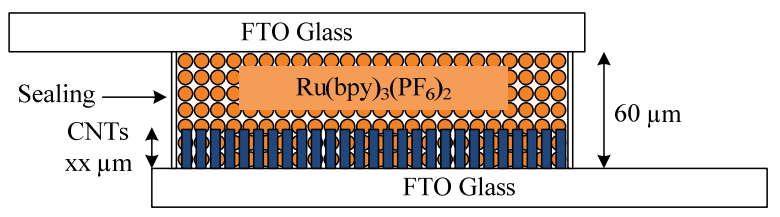

Fig. 1. The schematic of ECL cell with CNTs

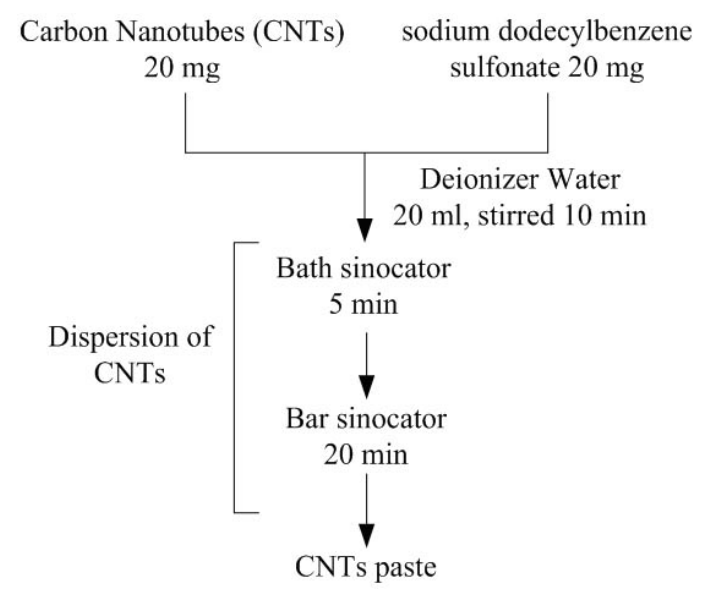

Fig. 2. The process of CNTs paste

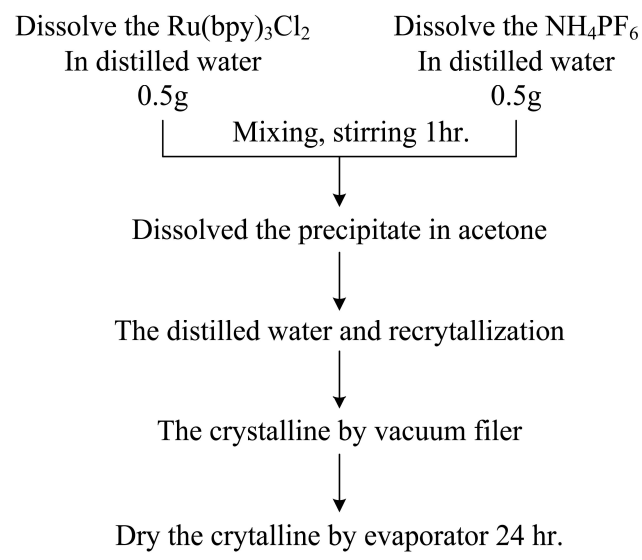

Fig. 3. The process of $\mathrm{Ru}(\mathrm{bpy})_{3}\left(\mathrm{FP}_{6}\right)_{2}$.

The precipitate of $\mathrm{Ru}(\mathrm{bpy})_{3}\left(\mathrm{FP}_{6}\right)_{2}$ was dissolved in the acetone. The precipitates were collected from recrystallization via distilled water. After that, the crystalline collected by and dried under vacuum for $24 \mathrm{~h}$ [7]. The $\mathrm{Ru}(\mathrm{bpy})_{3}\left(\mathrm{FP}_{6}\right)_{2}$ powder and $\mathrm{PC}$ solution ratio are achieved at $0.04 \mathrm{~g}: 0.448 \mathrm{~g}$ for $[19-20]$. Fig. 3 shows the process of $\mathrm{Ru}(\mathrm{bpy})_{3}\left(\mathrm{FP}_{6}\right)_{2}$.

For fabrications of a CNTs-based ECL cell, FTO glass with size an area $2 \times 3 \mathrm{~cm}^{2}$ was washed by ultrasonic (JAC 4020 ) and dried at $120{ }^{\circ} \mathrm{C}$ [7]. A layer of CNTs was coated on the FTO glass by a spin coater (ACE-1020 Series) in the area of $1 \times 1 \mathrm{~cm}^{2}$, followed by annealing at $450^{\circ} \mathrm{C}$ for 30 min. The coated CNTs on FTO glass was operated at thickness $1,3,5$ and $7 \mu \mathrm{m}$. The two electrodes were sealed by polymer spacers (Himilian; DuPont-Mitsui Polychemicals, thickness $60 \mu \mathrm{m}$ ). The Ru(II) solution of $0.16 \mathrm{M}$ with PC was injected into the gap between two electrodes $[1,19]$.

The ECL cell using CNTs electrode was measuring luminescence intensity and the current-voltage characteristics. All characteristics were measured using a spectroradiometer (Konica Minolta, CS-2000), an arbitrary waveform generator (Agilent, 33250A), and a digital storage oscilloscope (HAMAG, HMO1024).

\section{Experimental Results}

In this paper, ECL cell using CNTs electrode measurement are to be divided by its physical characteristics, electrical properties, and optical properties, also to find more suitable of the thickness of the CNTs electrode for ECL device. In physical characteristic side, is to analyze the crystallization at both of the structure surfaces.

Fig. 4 (a) and (b) are shown photographs of CNTs and annealing CNTs paste coated on FTO glass. In Fig. 4(a) is show the product of CNT, which made from the process the CNT solution in Fig. 2. The CNTs paste coated on FTO glass using by spin coater in area $1 \times 1 \mathrm{~cm}^{2}$, (right) and annealing at $450^{\circ} \mathrm{C}$ (left), can show in Fig. 4(b). The SEM 
(a)
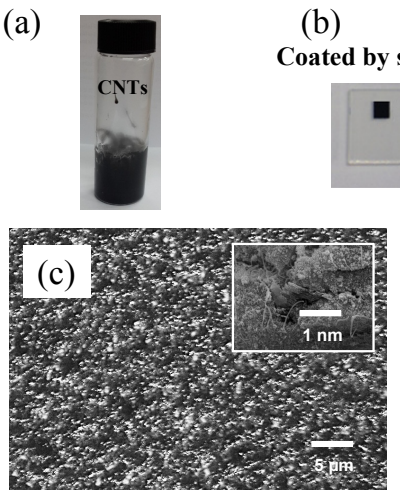

(b)
Coated by spin coater
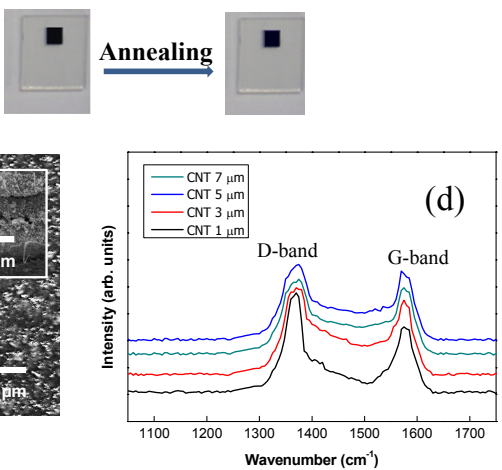

Fig. 4. Characterization of CNTs paste (a) Photograph of a vial of CNTs (b) Photograph of coating and paste. (c) SEM image of the CNT thickness-5 $\mu \mathrm{m}$ coated on an FTO glass. (d) Raman spectrum of the CNTs

image of CNTs at $5 \mu \mathrm{m}$ of thickness was measured by scanning electron microscopy (SEM, Hitachi S-3000H), can show Fig. 4(c). It resembles the shape of a growing tube, show in Fig. 4(c) inset. There is an array scattered on the surface. The mass and the surfactant of CNTs were $0.45-0.48 \mathrm{mg}$ and a CNT density of $0.23-0.25 \mathrm{mg} / \mathrm{cm}^{2}$. The quality of the CNTs was measured by MultiRAM FTRaman spectrometer (Bruker, Raman ScopeIII). The peak intensity of CNTs was showed by Raman spectroscopy (Fig. 4(d)). The specific surface area of the CNTs investigated by the Brunauer-Emmett-Teller (BET) method was $454.2 \mathrm{~m}^{2} / \mathrm{g}$.

The ECL cell represents the electrode material, thus the sample thickness of CNT electrode and ECL without CNTs electrode have the following configurations: FTO glass / Ru(II) / CNT(thickness-1 $\mu \mathrm{m}$ ) / FTO glass, FTO glass / Ru(II) / CNT(thickness-3 $\mu \mathrm{m}$ ) / FTO glass, FTO glass / Ru(II) / CNT(thickness-5 $\mu \mathrm{m}$ ) / FTO glass, FTO glass / Ru(II) / CNTs(thickness-7 $\mu \mathrm{m}$ ) / FTO glass and FTO glass / Ru(II) / FTO glass, respectively.

The intensity distributions of the thickness of CNTs for ECL cells are shown in Fig. 5. The peak intensity was $\sim 625$ $\mathrm{nm}$ of without CNT and $620 \mathrm{~nm}$ of CNTs-based ECL cell, which is very similar, is almost no effect on all electrodes. All electrodes of the ECL cells were showed responds dark orange emission of the ECL cell, and confirmed not to influence ECL device's luminous color. The peak intensity of CNT-7 $\mu \mathrm{m}$ less than that CNT-5 $\mu \mathrm{m}$ due to the collision of electrons and $\mathrm{Ru}(\mathrm{II})^{+}$(mean free path) in the CNT causing light intensity was decreased.

For the electrical properties, the sheet resistance of CNTs electrode was $8.45 \Omega /$ sq of CNT- $1 \mu \mathrm{m}, 8.95 \Omega / \mathrm{sq}$ of CNT-3 $\mu \mathrm{m}, 9.25 \Omega / \mathrm{sq}$ of CNT-5 $\mu \mathrm{m}$ and $9.46 \Omega /$ sq of CNT$7 \mu \mathrm{m}$. The applied voltage and frequency on cells are $0-5 \mathrm{~V}$ and $60 \mathrm{~Hz}$ for tested. The output current of CNTs-based on ECL cells were $28 \mathrm{~mA}$ for CNT-1 $\mu \mathrm{m}, 37 \mathrm{~mA}$ for CNT-3 $\mu \mathrm{m}, 48 \mathrm{~mA}$ for CNT-5 $\mu \mathrm{m}, 46 \mathrm{~mA}$ for CNT-7 $\mu \mathrm{m}$ and 21

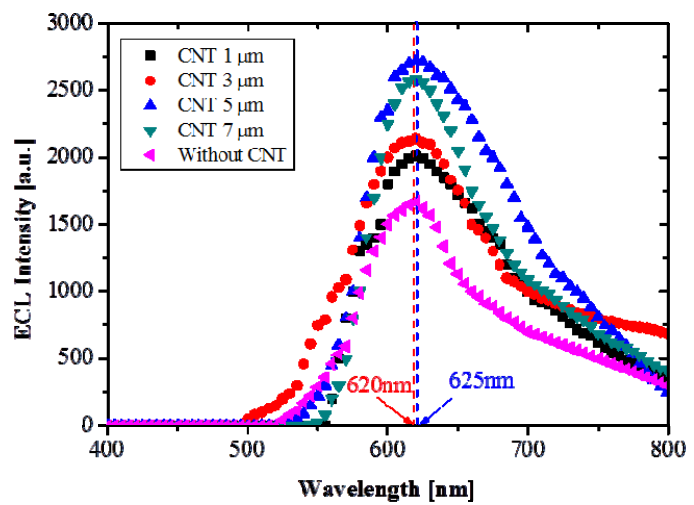

Fig. 5. The intensity distribution of ECL cell with thickness of CNT $1 \mu \mathrm{m}$, CNT $3 \mu \mathrm{m}$, CNT $5 \mu \mathrm{m}$, CNT $7 \mu \mathrm{m}$ and without CNT

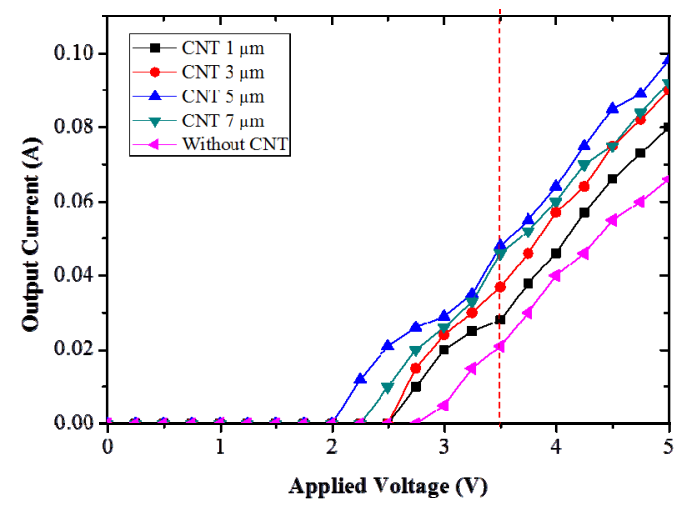

Fig. 6. The I-V curve of thickness of CNTs-based on ECL cell at CNT $1 \mu \mathrm{m}$, CNT $3 \mu \mathrm{m}$, CNT $5 \mu \mathrm{m}$, CNT 7 $\mu \mathrm{m}$ and without $\mathrm{CNT}$

$\mathrm{mA}$ for without CNT at $3.5 \mathrm{~V} 60 \mathrm{~Hz}$, show in Fig. 6. The current of CNT-5 $\mu \mathrm{m}$ was more than these CNTs and without CNT due to the large area surface on CNT reflected electrons in reducing reaction with $\mathrm{Ru}(\mathrm{bpy})_{3}{ }^{2+}$.

Fig. 7 shows the relationship between luminance and the thickness of CNTs-based on ECL cell. The applied voltage was $0-5 \mathrm{~V}$, the frequency is $60 \mathrm{~Hz}$.

Here nanotubes represent a cell with CNTs of thickness at $1,3,5$ and $7 \mu \mathrm{m}$, respectively. The threshold voltage of the light emission start was $2.25 \mathrm{~V}$ for CNT-5 $\mu \mathrm{m}$, which was lower than $2.75 \mathrm{~V}$ for CNTs $1 \mu \mathrm{m}$ and $3 \mu \mathrm{m}, 2.5 \mathrm{~V}$ for CNTs $7 \mu \mathrm{m}$ and $3 \mathrm{~V}$ for the cell without CNTs. In addition, the threshold voltage decreases with increasing the thickness of CNTs-based on ECL cells.

This result shows the decrease of the threshold voltage is related with the CNTs structure. The luminance of thickness of CNTs-based on ECL cell were $7.21 \mathrm{~cd} / \mathrm{m}^{2}$ for CNT-1 $\mu \mathrm{m}, 10.11 \mathrm{~cd} / \mathrm{m}^{2}$ for CNT-3 $\mu \mathrm{m}, 15.02 \mathrm{~cd} / \mathrm{m}^{2}$ for CNT-5 $\mu \mathrm{m}, 13.21 \mathrm{~cd} / \mathrm{m}^{2}$ for CNT-7 $\mu \mathrm{m}$ and $5.05 \mathrm{~cd} / \mathrm{m}^{2}$ for without CNT at $3.5 \mathrm{~V} 60 \mathrm{~Hz}$. The CNT-5 $\mu \mathrm{m}$ was maximum luminance because the large surface area of the CNTs would be responsible for the higher output current and electrons can diffuse in the CNTs $[15,17]$. 


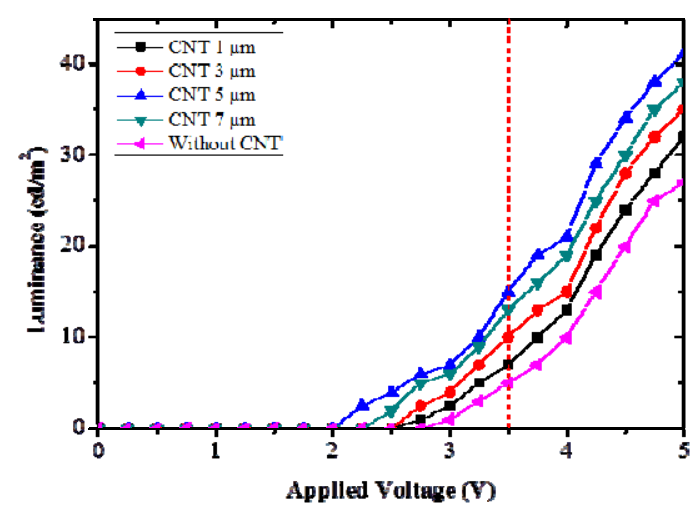

Fig. 7. The luminance of thickness of CNTs-based on ECL cell at CNT $1 \mu \mathrm{m}, \mathrm{CNT} 3 \mu \mathrm{m}$, CNT $5 \mu \mathrm{m}$, CNT 7 $\mu \mathrm{m}$ and without $\mathrm{CNT}$

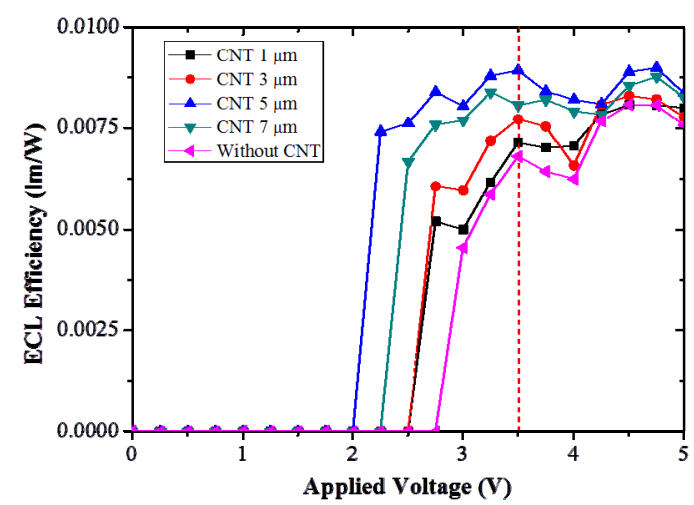

Fig. 8. The ECL efficiency of CNTs-based on ECL cell at CNT $1 \mu \mathrm{m}$, CNT $3 \mu \mathrm{m}$, CNT $5 \mu \mathrm{m}$, CNT $7 \mu \mathrm{m}$ and without CNT.

The efficiency of ECL cell can calculate from light intensity per electrical power $(\mathrm{lm} / \mathrm{W})$, the following equation: $[7,21]$

$$
E f f_{E C L}=\frac{I_{V} \cdot A_{\text {surf }}}{V \cdot I_{\text {out }}},
$$

when $I_{V}$ is intensity $\left(\mathrm{cd} / \mathrm{m}^{2}\right)$ and $A_{\text {surf }}$ is emission surface $\left(\mathrm{m}^{2}\right)$. At $3.5 \mathrm{~V}$, the efficiencies were $0.00714 \mathrm{~lm} / \mathrm{W}$ for CNT-1 $\mu \mathrm{m}, 0.00772 \mathrm{~lm} / \mathrm{W}$ for CNT-3 $\mu \mathrm{m}, 0.00893 \mathrm{~lm} / \mathrm{W}$ for CNT-5 $\mu \mathrm{m}, 0.00807 \mathrm{~lm} / \mathrm{W}$ for CNT-7 $\mu \mathrm{m}$ and 0.0068 $\mathrm{lm} / \mathrm{W}$ for without CNT, show in Fig. 8. The maximum of ECL efficiency was in the 4-5 V. The applied voltage increases causing the ECL efficiency were decreased due to the luminance and current are small increase make for efficiency is decreased followed reports [7, 19].

\section{Conclusion}

This paper presents the results of electrode material used by CNTs electrodes in ECL cell device. The performance of ECL cell with the nano-electrode material was CNTs for light emission. The thickness of CNT-5 $\mu \mathrm{m}$ has been lightemitting more than cell other CNTs and without CNTs electrodes. The threshold voltage of light emission starts of CNT-5 $\mu \mathrm{m}$ was lower than other CNTs, and $3 \mathrm{~V}$ for the cell without CNTs. The maximum output current was $48 \mathrm{~mA}$ for CNT-5 $\mu \mathrm{m}$ (At $3.5 \mathrm{~V}$ ), which more than cells other thickness of CNTs and without CNT electrodes. The applied voltage maximum ECL efficiencies of CNTs were 4-5 V. The voltage increases, causing the ECL efficiencies of the thickness of CNTs are decreasing. The peak intensity of CNTs-based on ECL cell was $\sim 625 \mathrm{~nm}$ of without CNT and $\sim 620 \mathrm{~nm}$ of CNTs-based ECL cell, which is very similar for color, have been responded dark orange color which was not influenced by the change in electrode material. The ECL cell with CNTs showed optimum for light emission was more than $5 \%$ for comparable other CNTs and ECL without CNT electrodes. The CNTs electrode can be improved light emission performance of ECL cell.

\section{Acknowledgements}

This research was financially supported by the Ministry of Education, Science Technology (MEST) and the National Research Foundation of Korea (NRF) through the Human Resource Training Project for Regional Innovation. This research (Grants No. C0193902) was supported by Business for Academic-Industrial Cooperative Establishments funded by Korea Small and Medium Business Administration in 2015.

\section{References}

[1] Y. M. Sung and H. J. Kim, "Sputter deposition and surface treatment of $\mathrm{TiO}_{2}$ films for dye-sensitized solar cells using reactive RF plasma," Thin Solid Films, vol. 515, pp. 4996-4999, 2007.

[2] M. Takase, S. Sugimoto, K. Nakamura, and N. Kobayashi, "Effect of $\mathrm{TiO}_{2}$ nanoparticle on electro chemiluminescent properties in $\mathrm{Ru}(\mathrm{bpy})_{3}$ - based emissive display," Disp. Image, vol. 1, pp. 97-104, 2013.

[3] X. Li, Y. Li, R. Feng, D.Wu, Y. Zhang, H. Li, B. Du, and Q. Wei, "Ultrasensitive electrochemiluminescence immunosensor based on $\mathrm{Ru}(\mathrm{bpy})_{3}{ }^{2+}$ and $\mathrm{Ag}$ nanoparticles doped SBA-15 for detection of cancer antigen 15-3," Sens. Actuators B: Chem, vol.188 pp. 642-645, 2013.

[4] Z. Q. Pan, C. G. Shi, H. F., N. B., C. M. Yu, Y. Liu, R. Lu, Q. H. Zhang, and H. Y. Gu, "Multiwall carbon nanotube-CdS / hemoglobin multilayer films for electrochemical and electrochemiluminescent biosensing," Sens. Actuators B: Chem, vol. 174, pp. 421426, 2012.

[5] A. J. Bard and L. R. Faulkner, Electrochemical 
Methods Fundamentals and Applications: Wiley, New York, 2001) P.15.

[6] M. M. Richter, "Electrochemiluminescence (ECL)," Chem. Rev, vol. 104, no. 6, pp. 3003-3036, 2004.

[7] H. D. Park, Y. M. Sung, M. W. Park, and J. E. Song, "Comparison of electrochemical luminescence characteristics of titanium dioxide films prepared by sputtering and sol-gel consumption methods," Jpn. J. Appl. Phys., vol. 52, pp. 05 EC04 (1-4), 2013.

[8] Y. K. Kwon and D. Toma'nek, "Electronic and structural properties of multiwall carbon nanotubes," Phys. Rev. B, vol. 58, pp. R16001(R), 1998.

[9] Hongjie Dai, "Carbon Nanotubes: Synthesis, Integration, and Properties," Accounts Chemical Research, vol. 35, pp. 1035-1044, 2002.

[10] Z. Xu, X. Chen, X. Qu, J. Jia, S. Dong, "Single wall carbon nanotube based voltammetric sensor and biosensor", Biosens Bioelectro, vol. 2, pp. 579-584, 2004.

[11] S. Musso, S. Porro, M. Rovere, A. Chiodoni, A. Tagliaferro, "Physical and mechanical properties of thick self standing layers of multiwall carbon nanotubes", Diamond Related Materials, vol. 16, pp. 1174-1178, 2007

[12] M. K. Choi, Y. M. Sung, and M. W. Park, "Optimum thickness conditions of $\mathrm{TiO}_{2}$ nanotubes layer for efficient electrochemical luminescence cells application," J. Nanosci. Nanotech., vol. 15, pp. 1499-1502, 2015.

[13] S. H. Oh and Y. M. Sung, "Fabrication of $\mathrm{ZnO}$ Nanorod-based Electrochemical Luminescence Cells and Fundamental Luminescence Properties," Trans. Korean. Inst. Elect. Eng., vol. 63, no. 1, pp. 76-79, 2014.

[14] H. Wei, E. Wang, "Solid-state electrochemi luminescence of tris(2,2-bipyridyl) ruthenium," Trends Analytical Chemistry, vol. 27, no. 5, pp. 447-459, 2008.

[15] Sanginario A., Demarchi D., Giorcelli M., and Castellino M., "Carbon nanotube electrodes for electrochemiluminescence biosensensors," Proceeding of International semiconductor conference, Sinaia (Romania), 11-13 October, pp. 195-198, 2010.

[16] E. Kymakis, M. M. Stylianakis, G. D. Spyropoulos, E. Stratakis, E. Koudoumas, and C. Fotakis, "Spin coated carbon nanotubes as the hole trans port layer inorganic photovoltaics," Solar Energy Materials \& Solar Cells, vol. 96, pp. 298-301, 2012.

[17] Ray H. Baughman, Anvar A. Zakhidov, and Walt A. de Heer, "Carbon nanotubes-the route toward applications," Science, vol. 297, pp. 787-792, 2002.

[18] Yu Jin Kang, Haegeun Chung, Chi-Hwan Han and Woong Kim, "All-solid-state flexible supercapacitors based on papers coated with carbon nanotubes and ionic-liquid-based gel electrolytes," Nanotechnology, vol. 23, no. 6, pp. 065401, 2012.

[19] Y. M. Sung, A. Chaoumead, and M. W. Park, "Electrochemiluminescence cell fabrication using $\mathrm{TiO}_{2}$ nanotube produced by anodic oxidation," J.
Nanosci. Nanotech., vol.11, 1-4, 2011.

[20] T. Nobeshima, K. Nakamura, and N. Kobayashi, "Reaction and improved performance of solutionbase electrochemiluminescence cell driven by alternating current," Jpn. J. Appl. Phys., vol. 52, pp. 05DC18 (1-4), 2013.

[21] P. Chansri and Y. M. Sung, "Synthesis and characterization of $\mathrm{TiO}_{2}$ on $\mathrm{ZnO}$-nanorod layer for highefficiency electrochemiluminescence cell application", Jpn. J. Appl. Phys., Vol. 55, No. 2S, 02BB11 (1-5), 2016.

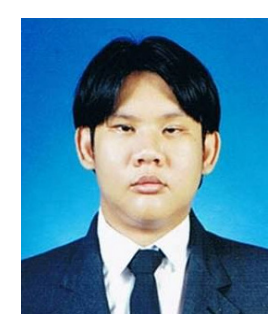

Pakpoom Chansri He received B. Ind. Tech. degree in electrical engineering from Srinakharinwirot University, Thailand in 2002 and M. Eng. degree in electrical engineering from King Mongkut's University of Technology Thonburi in 2007, Thailand. From 2007 to 2013, he worked as a lecturer at Faculty of Industrial Education and Technology, King Mongkut's University of Technology Thonburi, Thailand. He is currently a Ph.D student at Department of Electrical and Electronic Engineering, Kyungsung University, Busan, Korea. His research interests include light-emitting device (ECL, LED, EL), thin films process, and their application.

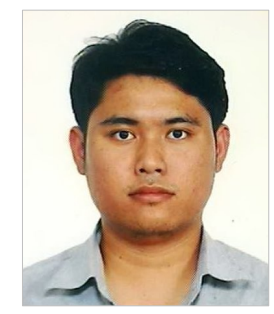

Pattarapom Pooyodying He received B.E. in electrical engineering from Rajamangala University of Technology Rattanakosin, Thailand in 2015. He is currently a Master student at Department of Electrical and Electronic Engineering, Kyungsung University, Busan, Korea. His research interests include light-emitting device (ECL, LED, EL), thin films process, Renewable energy and their application

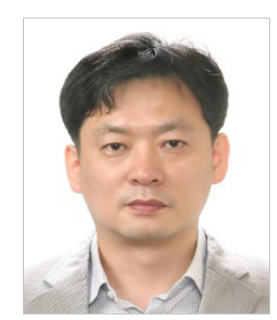

Youl-Moon Sung $\mathrm{He}$ received the Bachelor's, M.S., and Ph.D. degrees in electrical engineering from Pusan National University, Busan, Korea, in 1992, 1994, and 1996, respectively. From 1997 to 1998, he held a postdoctoral position with Kyushu University, Fukuoka, Japan. In 1999, he became a Research Associate with Kyushu University. In 2004, he became an Associate Professor with the University of Miyazaki, Miyazaki, Japan. He is currently a Professor with the Department of Electrical and Electronic Engineering, Kyungsung University, Busan. His research interests include plasma-based energy materials and their application. 